\title{
The importance of law in flood risk management
}

\author{
G. Cirillo ${ }^{1} \&$ E. Albrecht ${ }^{2}$ \\ ${ }^{1}$ Department of Civil Engineering, University of Calabria, Italy \\ ${ }^{2}$ Department for Civil Law and Public Law with References to the Law of \\ Europe and the Environment, BTU Cottbus Senftenberg, Germany
}

\begin{abstract}
Floods are becoming a very huge problem in most developed and developing countries, due to natural and human-induced risks and threats, which occur at river areas. In many cases, catastrophic events are caused by some inadequate human behaviour connected to, inter alia, reduction of the natural water retention by land due to industrial purposes or exploitation of meadows along river basins; no maintenance of levees; not respecting hydrogeological equilibrium; or not considering technical prescriptions or provisions to build along river basins. The adoption of flood risk management and planning in flood-prone areas are priorities to be dealt with in many river areas, as the United Nations and European Union stated. In this context, law plays a fundamental role to identify protection structures and liabilities in river areas, to define regulations and provisions in all stages of risk management. This research is aimed at showing how law intervenes in flood risk management and which subjects are covered; the importance to assess legal provisions which influence flood management or more generally water and river basin management and the interconnection at international, national and local level.

Keywords: flood risk management law, risk emergency law, flood risk plan.
\end{abstract}

\section{Introduction}

The management of flood emergencies as devastating event is recently increasing and becoming more frequent and even more dangerous than other natural risks. It is due to many effects in many cases related to the exploitation of soil, hydrogeological instability but climate change has an important influence as well. 
Human behaviour embodies a risk for the protection of rivers and surrounding areas, inter alia, such as reduction of the natural water retention by land used for industrial purposes or exploitation of meadows along river shores; no maintenance of levees; building along rivers without any control or respect of hydrogeological analysis, not respecting the provisions of laws or not considering technical standards.

Many of these aspects are regulated in legal acts and their treatment are strictly governed by law, and different law prescriptions to manage river basin or usage of water, building in risk-exposed areas are continuously enacted by governmental institutions. Within this global context, an important role is played by law at different stages; international, national and local level, to govern flood management, river basin management, usage of surface waters, environmental sustainability and in general the protection of water.

The international community has showed the importance to work on legal issues at worldwide level to bind countries to develop flood risk management policies, recurring to planning actions to mitigate risks and to protect populations and territories, involving different expertise.

\section{International framework and global vision of the water and flood management}

"ECE Convention on the Protection and Use of Transboundary Watercourses and International Lakes", known as "Water Convention", [1] can be considered as the starting law which has influenced the global vision of the question of flood management as part of the more general water and river basin management.

It was enacted in 1992 and entered into force on 6th October 1996, and succeeding acts were added to its first version to introduce operative protocol or to enforce some subject of matters [2]. It aims to protect and to ensure a sustainable usage of transboundary water resources by facilitating cooperation. It is structured as an intergovernmental platform to develop collaboration above all among riparian States to enforce integrated measures for a sustainable transboundary water management. The transboundarity is the main characteristic of the convention, such as:

1) Protection of water resources, in particular river basin;

2) Introduction of a reasonable usage of waters aimed to reduce the environmental impact and to avoid the exploitation of river basin;

3) Cooperation by enacting into specific agreements and establishing of joint management bodies.

The Water Convention as global platform does not replace multilateral or bilateral agreements that are already in force between State Parties, but invites Parties to comply with its provisions and to eliminate all potential contradictions with the basic principle of the Convention [3].

This research intends to highlight how planning is considered at different levels, the only possible solution to manage territories, rivers, water resources and soil and to avoid catastrophic events. 
Planning and risk management were given prominence by Water Convention and its addenda and executive documents, discussed and issued during international meeting of Convention Parties. In the meeting held at The Hague in March 2000, the Guidelines of sustainable flood prevention were approved [4]. They affirm the necessity to create legal and administrative frameworks to make all stakeholders active to contribute to flood prevention, to reduce adverse impact and dangerous consequences of flood events. They identify and introduce the concept of preventive measures, comprising primary preventive measures which include all those legal prescriptions referred to how to build, to locate structures away from flood-prone areas; early warning and technical standards; secondary preventive measures which include all those response activities to be done to contain damages and how to act during a flood and recovery phase. In the basic principle, the Water Convention affirms the importance of cooperation at governmental levels and coordination of different policies to deal with flood which is a natural event and only the human intervention or interference can cause worst consequences or amplify the damages. And so, all aspects of behaviour should be driven by the "precautionary principle". The question to cooperate for river management was discussed in the meeting held in Bonn in November 2006 by State Parties, and it brought to draft a Model Provision on Transboundary Flood Management [5]. This Model establishes a long-term cooperation between riparian States, by virtue of a joined long-term management of the river basin, through a continuous exchanging of hydrological and meteorological data, preparation of studies, surveys, flood plains, flood areas and risk maps, flood risk assessments. It aims to develop a comprehensive flood action plan addressing prevention, protection, preparedness and response to integrated flood plan management, by means of the creation of a management model to use as a base for further normative instruments in bilateral or multilateral level to head prevention, protection and mitigation actions. The implementation at domestic level is devolved to State Parties to make stronger the "soft-law" of international agreements and protocols. The Guide to implementing the Convention on the Protection and Use of Transboundary Watercourses and International Lakes adopted in the meeting of Geneva in November 2009 [6], with the main objective to assist State Parties to implement the Water Convention into domestic law, setting out legal and procedural issues and features to be evaluated in the ratification process and transposition of international provisions into national law framework of riparian States. Following the precautionary principle, it set forth to activate cooperative measures and joined or integrated plans. Underlining the importance to introduce measures and provisions in national jurisdictions to make the effects of pronouncements claimed by Water Convention more binding.

\section{European law on flood management}

The technical definition of flood is a temporary covering by water of land not normally covered by water, as adopted in Directive 2007/60/EC [7]. Law perspective starts from definitions to identify the subject of matter to be dealt with and to identify actions and introduce prescriptions aimed at Member States. 
Directive prescriptions bind Member States in the achievement of results mainly in those cases where they are very well detailed in contents and subjects. In fact, one of the main problems, falling within relation between European Law and Member States Law, is the transposition and related measures of Directive prescriptions to transfer from EU level into national level. European Court of Justice intervened by different sentences ruling that the implementation of directives into domestic law does not necessarily require a specific law enacted on purpose, as measure of transposition, but it is fundamental to introduce clear and fair provisions, recurring to the national measures provided by domestic law framework [8].

The Directive 2007/60/EC, known as Flood Directive, laid this question as well, also due to the complicated system and stakeholders to be involved in. In line with the Water Convention, in 2007, the European Parliament and Council enacted the Flood Directive on the assessment and management of flood risks, which succeeds other European formal acts, such as:

1) Directive 2000/60/EC [9] for water policies, which has introduced, inter alia, the importance to develop a river basin management plan and related actions to increase resilience in certain areas exposed to risks and to improve awareness and policies towards flood damages;

2) Council Decision 2001/792/EC Euratom [10] which established a Community mechanism to reinforce cooperation in civil protection assistance to give an adequate response to population or territories affected by catastrophic events and to enforce preparedness and resilience mechanisms and systems;

3) European Commission Communication of 12 July 2004 [11] named "Flood risk management - Flood prevention, protection and mitigation" which has introduced the need of joined analysis at Community level and the development of concerted and coordinated action at States level in flood risk management.

The main purpose of the Directive, as it sets forth in the art. 1 of General provisions is to establish a framework for the assessment and management of flood risks, aiming to avoid or to reduce dangerous effects for human health, environment, cultural heritage and economic activities. These four points, as reported in many articles of the Directive, are the fundamental sectors to be protected and they drive risk protection policies. In fact, the evaluation of global situation in a circumscribed area becomes a priority to verify the potential resilience to flood, taking in the due account factors like population, level of urbanization, presence of cultural properties and human settlements, economic businesses and it should analyse all those elements which could cause or worsen the devastating effects in case a flood event occurs.

The Directive provides important steps and actions to be undertaken in the assessment procedures by Member States aimed at establishing a protection framework, as reported in the different Chapters and Articles:

1) Appointment of competent authorities, identification of river basins and the related managing authority. This is a preliminary commitment assigned to the States, because it is fundamental to establish who is in charge of 
responsibilities in the management and protection of the area and who shall respond in case of adverse consequences affecting river district and local communities living in or cultural heritage and economic activity placed in. The tasks of these authorities are coordinated but not overlapped with authorities who manage river basin district provided in the Directive 2000/60/EC (Art. 3), because the role is different;

2) Preliminary Flood Risk Assessment (Chapter II, art. 4-5), which should contain information related to: maps of river basin district; historical reconstruction of previous floods and significant damages caused and impact on the territory also to envisage future catastrophic events like occurred in the past. The adverse consequences of flood for the four points indicated above human health, the environment, cultural heritage and economic activities should not be overlooked. The assessment activities should be elaborated taking into account elements such as topography of the area, the river basin, the flow of watercourses; hydrological and geomorphological characteristics, floodplains and natural retention areas;

3) Mapping (Chapter III, art. 6), this section provides two different types of maps: Flood Hazard Maps and Flood Risk Maps. The former should cover floods scenarios, identifying the level of probability of occurrence in low, medium or high, the latter should consider all those elements which are important in the evaluation of potential adverse consequences, such as number of inhabitants, economic activity, level and sources of pollution;

4) Flood Risk management (Chapter IV, art. 7-8), Member States should provide river basin district with a flood risk management plan considering various points, such as measures to reduce adverse consequences of flooding for human health, the environment, cultural heritage, economic activity and adoption of non-structural initiatives as well; establishment of an early warning system; analysis of costs and benefits, flood retention areas; evaluation of catchment river basin; sustainable land use practices.

This last point is the core of the Directive and of the EU flood policy as well. The Flood Directive is the formalisation of initiatives, discussions, argumentations and projects undertaken by European Institutions and most of the Members States. The main objective of flood risk management is the reduction of likelihood or dramatic impact of floods, taking into consideration few basic elements, as identified in the Flood Directive and in the COM (2004)472. The basic elements identified are the prevention of damages caused by floods by avoiding some activities which can bring about, or contribute to bring about, adverse consequences, such as an excessive exploitation of soil, construction of houses and industries or human settlements in present and future flood-prone areas; by introducing system of warning and control of potential risks; by adapting future developments to the risk of flooding; and by promoting appropriate land-use, agricultural and forestry practices. Strictly related is the concept of protection by adopting measures, both structural and non-structural, to reduce the likelihood of floods and/or the impact of floods in a specific location. The other basic elements to be considered are the preparedness of informing the population about flood risks and what to do in the event of a flood, through information campaign. 
Subsequently the development of an emergency response plans in the case of a flood, involving public authorities, such as civil protection services, army or police or all those bodies who work in first aid, but private organizations, businesses, association and non-profit organization as well. Consequentially the recovery aspect of returning to normal conditions in quickest way putting into action all strategies and structures available and of mitigating both the social and economic impacts on the affected population.

In the establishment of flood risk management plan - annex of Flood Directive - and following the Guidelines for the development and implementation of flood risk management plans and flood risk maps - annex of $\operatorname{COM}(2004) 472$, the foremost components are: the results of preliminary assessment; the drafting of flood hazard and risks maps; the protection measures and a cost-benefit analysis. In the description of implementation of the plan, public information and identification of competent authorities are listed as fundamental points of the plan. But any commitments related to the analysis of law or legal acts which could be important in the setting out of the plan.

The Flood Directive has provided general provisions requiring Members States to detail each matter, from planning to identification of competent authorities, through the ratification process requested for the entry into force in Members States domestic jurisdiction.

The present research is focussed on two Member States, where the Flood Directive has been implemented by national laws: Germany and Italy, and two real cases, one in Germany and another in Italy, which had adverse consequences on population and territory and on cultural heritage were analysed.

\subsection{Germany Federal Water Act (Wasserhaushaltsgesetz) competencies and flood management}

The Flood Directive in Germany was incorporated into "Federal Water Act WHG Wasserhaushaltsgesetz" - of 31st July 2009 whose last amended version entered into force on 1st March 2010 [12, 13]. According to German Basic Law (Grundgesetz), the competencies related to water management resources fall into concurrent legislative powers, as stated by art. 72 - Par. 3, no. 5, between Federal Government and States (Länder). After reform, the Federation has the competence in the matter of water management and consequentially of the transposition of flood directive into domestic law. Federal States have the competence for the administration of laws, including federal laws, and the responsibility for the regulation and for the different administrative levels [14]. In most of Federal States, a three-level structure was adopted:

1) A Superior authority, the Environment Ministry with control and general administrative procedures competencies;

2) A Middle authority, province government, which are in charge of adoption of regional water management planning in general and all those procedures under the water management act; 
3) Lower authorities, local or district authorities which have tasks related to follow the procedures on the spot of water management act and monitoring bodies and discharges.

Before the WHG, in 2005, German Parliament (Bundestag) had enacted the "Act to Improve Preventive Flood Control" whose main amendments were transposed into water national law of 2002. According to this act, States have much power in flood management referred to the divulgation of information about risks to authorities and population; the determination, mapping and preservation of floodplains; the adoption of preventive measures of protection, such as flood-proof installations or necessary to avoid damages; the identification of prevention measures in flood-prone areas and the drafting and definition of flood control plans [15].

The most of law provisions into force related to flood management are disciplined at States level and subsequently at lower administrative level, such as municipalities and districts, responding to European subsidiary principle.

The efficacy of this framework was tested during floods that occurred in Germany. The research is focussed on the case that happened in 2013 along Elbe River, which caused much damages for persons, structures, environment and cultural heritage placed in the inundated plains and territories.

The massive flooding along Elbe River from the 26th May to 2nd June 2013, was caused by a huge quantity of rain fell down, about 22.76 trillion litres. In the same places, in Elbe Valley, where in 2002 another catastrophic flood occurred, named at the time as the "flood of the century". From different points of view and evaluating the case, many reasons caused the disaster, and many of them are still analysing, also because strictly connected to political decision. But the only certainty is that, in 2003, some States, Lower Saxony, Saxony-Anhalt, Saxony, Schleswig-Holstein, Meckleburg-Western Pomerania and Brandenburg, invested some 480 million euro to adopt an "Action plan" [16]. But the entity of damages was very different in each States affected by flood. The event occurred and so what was wrong?

Elbe is one of the river basins listed in article $1 \mathrm{~b}$ of WHG, an International Commission of Protection officialised by a Convention signed between Germany, Czech and Slovakia Federal Republic and former European Economic Community in 1990.

Many experts, with different competencies, were called to cooperate in the analysis of the specific case Elbe, to try to verify why in a so short period of time the problem of floods happened again and to retrace the timeline of the event. Among these, Jürgen Stamm, Professor of Hydraulic Engineering at the Technical University in Dresden, who affirmed the impossibility to regulate natural disasters with money, policies or law, but he raised, inter alia, the fragmented jurisdiction is a major problem [17], and each States cope with the problems of protection with measures which are considered adequate, such as levees or polders, following only their internal decisions and policies.

Already in the first report drafted by DKKV(German Committee for Disaster Reduction) in 2004 [18], two years after the 2002 Elbe flood occurred, highlighted how in the main points to be evaluated, there is also The splitting of responsibilities 
between the Federal Government, Government of the State of Saxony and the local authorities and the partly unclear designation of competence along (navigable) river reaches and the river catchments must be done away with, and instead clearly defined objectives and clear definitions of priorities are required.

It is evident how the law becomes important in the definition of liabilities of subjects involved and how the definition of competencies in the case of Elbe floods held a fundamental role, causing damages. In fact, in situations not strictly confined into a circumscribed territory but exceed boundaries, a central power could face up to the emergency in a more coordinated way, thanks to the fact it would have a global view throughout national territory and tap the fails and/or support the weaker zones. An estimation report by Zurich Insurance Company, published in May 2014 [19], pointed out that the German flood protection system lacks a comprehensive flood protection program or a national managing authority, to guarantee a global intervention in case of catastrophic events. The different flood protection authorities in charge in each State are a complication of the system, like Elbe floods revealed.

\subsection{Italy: River Basin Authority Establishment (Istituzione Autorità di Bacino), competencies and flood management}

The present research analysed another case study to verify the importance of law in flood management and protection system and the damages caused to cultural heritage. The analysis started from water law framework, like in the German case. The Italian flood management is based on different laws, enacted to deal with different emergencies, milestones are represented by:

1) Before the implementation of European Directives. The introduction of norms to reorganise functionally the soil protection by different laws and decrees (L.183/1989; L. 493/1993; L. 267/1998 n.; L. 365/2000; Prime Minister Decree issued 29th September 1998) which basically identified the hydrographic basins, the River Basin Authorities and basin plan, to set up all preservation, protection, defence and valorisation of the soil. Basin plan is considered as an upgrading means to preserve the hydrogeological, environmental, urban, agrarian, landscape integrity of the soil, introducing legal prescriptions related to constraints, directives, structural and nonstructural interventions aimed to the safeguard of water resources. They indicated criteria and methodologies to identify flood risks to be considered in the drafting of flood plan, following three main stages: identification of flood-prone areas, collecting information related to the degree of hydrogeological instability; assessment of risks level and definition of safeguard measures, thanks to these provisions, in Italy the prevention assessment, as Flood Directive provides, are skipped because it was already realized before the Directive issued; planning the mitigation of risks [20].

2) The implementation of Water Directive 2000/60/CE by Law Decree 152/2006 "Environmental Code" which repealed in part Law 189/1989, but maintained the tasks of River Basin Authorities and confirm provision to adopt flood plan. 
Decree 49/2010 which implemented the Flood Directive into national legislation, amended by Decree 219/2010.

According to the concurrent legislative and administrative power between central authority and local public authorities, the flood risk management in Italy is handled by:

1) District Basin Authority, in charge of drafting flood hazards and flood risks maps aimed to establish the flood management plan;

2) Regional Authority, in charge of drafting the flood management plan related to the specific hydrographic basin and the early warning system, in coordination with other Regional Authorities and with national Department of Civil Protection;

3) Province in charge of building and maintenance of water installation;

4) Municipalities in charge of adopting all safeguarding measures provided by flood plan and granting permissions and licenses in case of request [20].

The "test case" analysed in the Italian framework is represented by the flood of Crati, a small river which flows in a flat land, named Piana di Sibari, close to the Ionian sea and with a modest discharge 26.16 cubic meters per second. In January 2013, as consequences of an extraordinary rain, the flow of the river engrossed and in a specific point broke the levee and the run-off of water invaded a Magna Graecia archaeological site, which was covered totally with 200,000 cubic meters of water causing catastrophic damages to the ancient ruins. The main causes which contributed to the damage were related to weak levees, lack of maintenance and dredging to make the river flow runs, unauthorized cultivation in the flood plain.

The problem laid on a splitting of competencies between different authorities involved in controlling and maintaining the river (Province), in granting building licenses (Municipality), in supervising the respect of flood risk management plan (River Basin Authority and Region) and authorities in charge of protection of cultural properties (Minister of Cultural Goods and Tourism). In the phase of emergency, in fact, the Civil Protection units and municipalities involved did not enter into the archaeological area because this was out of their competence, which is handled by local offices of national Minister of Cultural Goods and Tourism.

\section{Conclusion}

The analysis of the flood has come to the fore the importance of the law in all phases related to flood policies, in the preliminary assessment, mapping and above all in the planning, where it is important to identify roles and responsibilities to control, to manage and to deal with flood adverse impact on territories and communities. The goal of the present research is to establish a model, like that experts use to collect hydrogeological, geographical, structural data and information to be considered in forthcoming planning activities, where to insert the analysis of laws. Following a methodology of gathering of all technical and scientific records related to the flood-prone area based on which legal provisions 
have an influence on the areas falling within flood-prone areas and population who live in.

In fact, in all examined documentations mentioned above, the planning is considered as the only solution to manage vulnerable territories, to control hazards and to mitigate risks, but planning investigations do not mention law as one of key factors to be considered in a pre-analysis of global situation. The analysis is most frequently aimed to the hydrogeology of the soil, the resilience of levees and river basin, the vulnerability of buildings and structures, both for housing and historical building and monuments, present in a flood-prone areas, the communication system is considered as well, but not the law into force in the analysed area. Even though many elements of this analysis will be transposed into succeeding law provisions.

The aim of the present research is to suggest the establishment of a model to be followed, like other expertise use to collect data and technical information, where to identify and to collect all different laws into force in a specific area, all those laws which can influence flood management. Mainly safeguarding law for human health and water, air and soil pollution; law related to urban planning, referred to how to build, which materials to use, the safety distances to be maintained between buildings; environmental law, to evaluate the environmental impact and law to protect and to preserve cultural heritage and landscape.

\section{References}

[1] The Economic Commission for Europe Water Convention and the United Nations Watercourses Convention An analysis of their harmonized contribution to international water law - Water Series № 6 United Nations, 2015.

[2] UNECE - United Nations Economic Commission for Europe Convention on the Protection and Use of Transboundary Watercourses and International Lakes, 1992, http://www.unece.org/env/water/text/text.html.

[3] Guruswamy Lakshman D. International Environmental Law in a nutshell West Publishing USA, 2012.

[4] UNECE - United Nations Economic Commission for Europe Guidelines on Sustainable Flood Prevention 2000 Report and Documentation http://www.unece.org/fileadmin/DAM/env/water/publications/documents/ guidelinesfloode.pdf.

[5] UNECE - United Nations Economic Commission for Europe Model Provisions on Transboundary Flood Management 2006 Report and Documentation http://www.unece.org/fileadmin/DAM/env/documents/ 2006/wat/ece.mp.wat.2006.4.e.pdf.

[6] UNECE - United Nations Economic Commission for Europe Guide to implementing the Convention on the Protection and Use of Transboundary Watercourses and International Lakes, 2009 Report and Documentation http://www.unece.org/fileadmin/DAM/env/documents/2009/Wat/mp_wat/ ECE.e.pdf. 
[7] Directive 2007/60/EC on the assessment and management of flood risks Official Journal of the European Union L 288, 6.11.2007, pp. 27-34.

[8] Knopp, L. and Albrecht, E. Transposition of the SEA Directive into National Law - Challenges and Possibilities, in: Schmidt/João/Albrecht (Hrsg.), Implementing Strategic Environmental Assessment, SpringerVerlag, Heidelberg, 2005, pp. 57-67.

[9] Directive 2000/60/EC establishing a framework for Community action in the field of water policy Official Journal of the European Union L 327, 22/12/2000, pp. 0001-0073.

[10] Decision 2001/792/EC, Euratom: Council Decision of 23 October 2001 establishing a Community mechanism to facilitate reinforced cooperation in civil protection assistance interventions Official Journal of the European Union L 297, 15.11.2001, pp. 7-11.

[11] $\operatorname{COM(2004)472~from~the~Commission~to~the~Council,~the~European~}$ Parliament and European Economic and Social Committee and the Committee of the Regions Flood Risk Management, Flood prevention, mitigation and protection Official Journal of the European Union C 49, 28 February 2006.

[12] Federal Minister for the Environment, Nature Conservation, Building and Nuclear Safety Water Framework Directive - Implementation of WFD programmes and measures, interim results 2012, 2013.

[13] Federal Minister for the Environment, Nature Conservation, Building and Nuclear Safety - Water Resources Management Part. 1 (Dec.2013) Fundamentals and Part.2 Water quality, 2013.

[14] Kotulla, M. Das Gesetz zur Verbesserung des vorbeugenden Hochwasserschutzes, NvWZ 2006, pp. 129-135.

[15] LAWA - German Working Group on Water Issues of the Federal States and the Federal Government Recommendations for the Establishment of Flood Risk Management Plans (March 2010).

[16] Der Spiegel After the Flood: Life in Germany's Disaster Zone $-12^{\text {th }}$ July 2013 http://www.spiegel.de/international/germany/multimedia-specialgerman-communities-rebuild-after-mass-flood-a-910812.html.

[17] Berger A. DW Top Stories German flood prevention can't prevent flood (12.06.2013).

[18] Grünewald U., Kaltofen M., Schümberg S., Merz B., Kreibich H., Petrow T., Thieken A., Streitz W., Dombrowsky WR - for DKKV - German Committee Flood Risk Reduction in Germany - Lessons learned from the 2002 Disaster in the Elbe Region, 2004.

[19] Zurich Risk Nexus Central European Central European floods 2013: a retrospective 2014.

[20] Minister of Environment, Protection of Territory and the Sea - Department of Protection of Territory and Water Resources - Documento conclusivo del Tavolo Tecnico Stato Regioni - Indirizzi operativi per l'attuazione della Direttiva 2007/60/CE Relativa alla valutazione ed alla gestione dei rischi da alluvioni con riferimento alla predisposizione delle mappe della pericolosità e del rischio di alluvioni (Decreto Legislativo n. 49/2010). 
[21] Regione Calabria Assessorato Ai Lavori Pubblici - Autorita' Di Bacino Regionale Piano Stralcio per l'Assetto Idrogeologico (PAI) (ai sensi dell'art. 1-bis della L. 365/2000, dell'art.17 Legge 18 maggio 1989 n.183, dell'art.1 Legge 3 agosto 1998 n. 267) Norme Di Attuazione e Misure Di Salvaguardia.

[22] Comune di Cassano All'Ionio Sibari: la storia, l'area archeologica e l'esondazione del Crati del 18.01.2013 - Report Dec. 2013. 